\title{
First records of Opilio saxatilis C. L. Koch, 1839 (Arachnida, Opiliones, Phalangiidae) from Serbia
}

\author{
Juraj Litavský, ${ }^{1}$ Oto Majzlan, ${ }^{1}$ Marek Svitok, ${ }^{2}$ Slavomír Stašiov ${ }^{2}$
}

1 Comenius University, Faculty of Natural Sciences, Department of Landscape Ecology, Ilkovicova 6, SK-842 15 Bratislava, Slovakia. 2 Technical University in Zvolen, Faculty of Ecology and Environmental Sciences, Department of Biology and General Ecology, T. G. Masaryka 24, SK-960 53 Zvolen, Slovakia.

Corresponding author: Marek Svitok, svitok@tuzvo.sk

\begin{abstract}
We report the first record of Opilio saxatilis C. L. Koch, 1839 (Arachnida, Opiliones, Phalangiidae) from Serbia. The species was observed in the alluvium of the Tisa River in the Special Nature Reserve Ritovi donjeg Potisja.
\end{abstract}

Key words

Harvestmen, alluvial forests, Tisa River.

Academic editor: Regiane Saturnino | Received 12 May 2017 | Accepted 2 February 2018 | Published 16 February 2018

Citation: Litavský J, Majzlan O, Svitok M, Stašiov S (2018) First records of Opilio saxatilis C. L. Koch, 1839 (Arachnida, Opiliones, Phalangiidae) from Serbia. Check List 14 (1): 257-260. https://doi.org/10.15560/14.1.257

\section{Introduction}

In total, 59 harvestman species of 7 families and 3 suborders were recorded in Serbia up to now (Čurčić et al. 1999, Karaman 1995). Majority of these species belongs to families Phalangiidae (19 sp.) and Nemastomatidae (17 sp.). The new record of harvestmen, Opilio saxatilis C. L. Koch, 1839 (Arachnida, Opiliones, Phalangiidae) and hiatus of several other species known from neighboring countries suggests that the current species list of Serbia is far from complete.

\section{Methods}

This research was carried out in 2015 and 2016 at 2 sites located in a floodplain of Tisa River, Serbia (Fig. 1): Site S1 $\left(45^{\circ} 22^{\prime} 50.76^{\prime \prime} \mathrm{N}, 020^{\circ} 13^{\prime} 40.83^{\prime \prime} \mathrm{E}, 74 \mathrm{~m}\right.$ above sea level (a.s.l)) represents flooded forest near an abandoned meander of the Tisa River with the tree canopy ( $90 \%$ cover) composed of Salix alba, Fraxinus pennsyl- vanica, Populus alba and Amorpha fruticosa. The site is often inundated in the spring. Site S2 $\left(45^{\circ} 23^{\prime} 25.07^{\prime \prime}\right.$ $\mathrm{N}, 020^{\circ} 13^{\prime} 16.15^{\prime \prime} \mathrm{E}, 71 \mathrm{~m}$ a.s.1.) is an ecotone between meadow and wetland with the tree canopy $(10 \%)$ composed of S. alba, A. fruticosa, Rubus caesius and herb layer with dominant Phragmites australis.

Harvestmen were captured by pitfall trapping using the plastic cups with the opening diameter of $7.5 \mathrm{~cm}$ and the volume of $0.5 \mathrm{~L}$. Fixation fluid in a trap (ca $1 / 3$ of the volume) was $1 \%$ formaldehyde. We placed 5 traps in the line with the $5 \mathrm{~m}$ distance between neighboring cups at each site. The traps were active from May to November in 2015 and from April to November in 2016. The traps were emptied at 1-month intervals. The content of traps was merged for each site and date and was treated as a composite sample per each sampling period. The obtained biological material was sorted in the laboratory. Harvestmen were prepared and subsequently determined to the species level according to Martens (1978). Voucher 

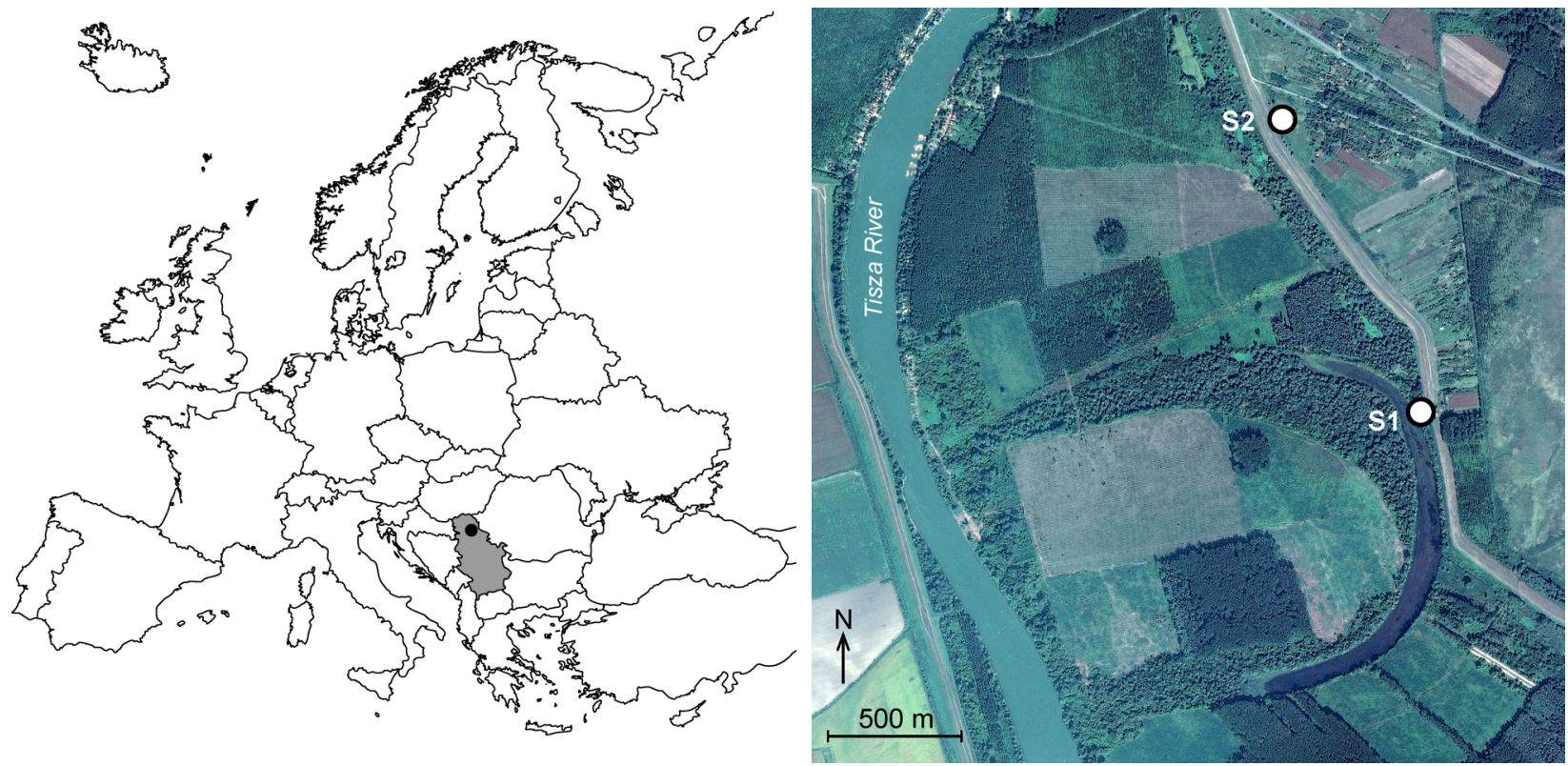

Figure 1. Map showing location of sampling sites with the new records of Opilio saxatilis in Serbia.

material was fixed in $80 \%$ ethanol and deposited in the collection of Department of Landscape Ecology, Comenius University, Faculty of Natural Sciences in Bratislava, Slovakia (UNIBA).

\section{Results}

Opilio saxatilis C. L. Koch, 1839

Figures 1-4

Opilio saxatilis was described by Koch (1839). The validity of this species was widely accepted by the later authors (Canestrini 1872, Simon 1879, Becker 1879, 1896, Pickard-Cambridge 1890, Falconer 1910). However, Roewer (1912) questioned the species status of $O$. saxatilis and supposed it to be the juvenile stage of $O$. parietinus (De Geer, 1778). This opinion was adopted by several other authors (e.g. Lessert 1917, Kästner 1928). Later, Hull (1930) suggested that O. saxatilis should represent a different species, while Savory (1945) also was not quite certain about the synonymy of saxatilis and parietinus. Šilhavý (1938) proved that the 2 species are really distinct. Moreover, based on the morphology of genital apparatus, he concluded that $O$. saxatilis (C. L. Koch) and the subspecies O. parietinus silhavyi Krat., 1934 are synonymous. Afterwards, Todd (1948) and Sankey (1949a) also demonstrated that $O$. saxatilis and $O$. parietinus differ in external morphological characters, in the structure of the genital apparatus, and in their ecology.

Diagnosis. Opilio saxatilis is morphologically very similar to Opilio parietinus, which has not been recorded in Serbia so far. Nevertheless, these species can be reliably distinguished by several marks. The extruded penis of O. saxatilis (Fig. 2), including the corpus, is $1.6-2.0 \mathrm{~mm}$ long and is stouter in proportion to its length when compared with that of $O$. parietinus, which is $2.7-3.1 \mathrm{~mm}$ long (Šilhavý 1956). The penis plates are elongated in
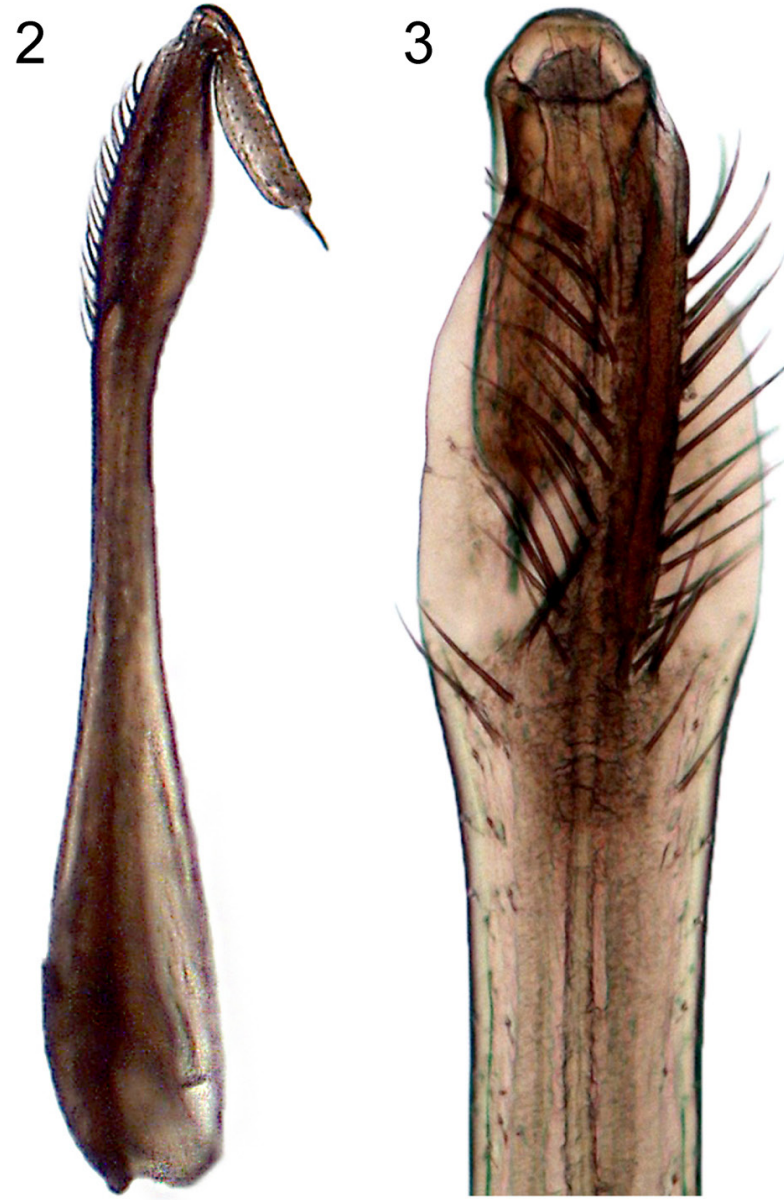

Figures 2, 3. Opilio saxatilis. 2. Overall view of penis.3. Detailed view of penis plates with bristles. Photographs by JL.

O. saxatilis, each with well-pronounced bristles (Fig. 3). These are somewhat reflexed and lie on the ventral surface. In contrast, the plates of $O$. parietinus are rounded and without bristles. Missing bristles are typical also for the other 3 Opilio species known from Serbia (O. putnik 


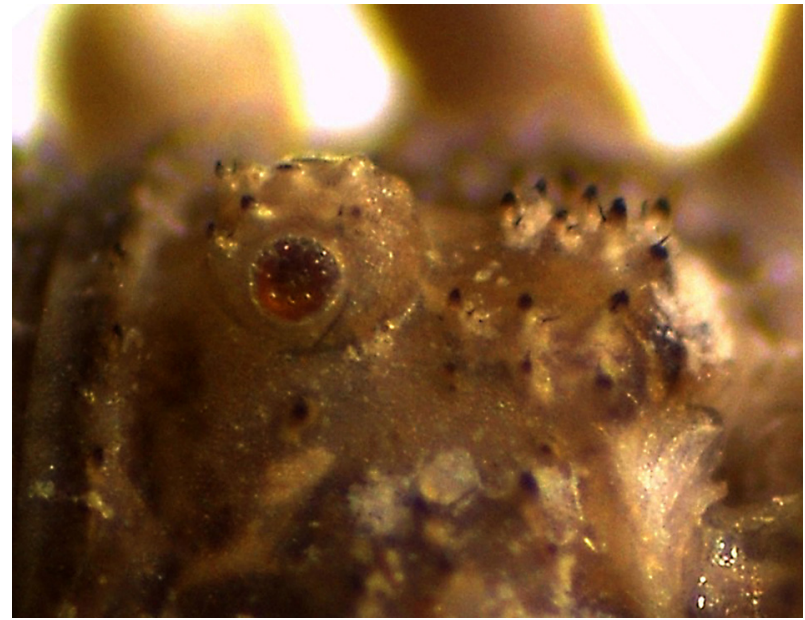

Figure 4. Ocularium of Opilio saxatilis with spines. Photograph by JL.

Karaman, 1999, O. ruzickai Šilhavý, 1938 and O. transversalis Roewer, 1956). In lateral view, the glans of $O$. saxatilis is less elongated and the distal tube is straighter and longer in proportion to the length of the glans compared with the corresponding organs of $O$. parietinus (Sankey 1949b).

Distribution. Opilio saxatilis is widespread nearly throughout the whole of Europe (it has not been recorded in Portugal, Spain, Norway, Finland, Switzerland, post-Soviet states with the exception of Lithuania, Montenegro, Macedonia, Greece, and Turkey) (Martens 1978, Milanovic 1990). An isolated population occurs in Israel near the town Ofer (Staręga 1966).

Material examined. Serbia: site S1 (45²2'50.76" N, 02013'40.83" E, 74 m a.s.l), col. J. Litavský, 30 August 2015-3 October 2015 (UNIBA-SRB-837, 1 ते adult). Serbia: site S1 (45²2'50.76" N, 020¹3'40.83" E, 74 m a.s.l), col. J. Litavský, 5 June 2016 - 8 July 2016 (UNIBASRB-838, 1 ○े adult). Serbia: site S1 (4522'50.76" N, 020 13'40.83" E, 74 m a.s.l), col. J. Litavský, 30 August 2015 - 3 October 2015 (UNIBA-SRB-842, 843, 2 ? juve-

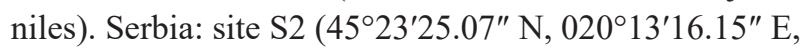
$71 \mathrm{~m}$ a.s.1.), col. J. Litavský, 30 August 2015 - 3 October 2015 (UNIBA-SRB-844, 845, 2 q subadults). Serbia: site S2 (452 $23^{\prime} 25.07^{\prime \prime} \mathrm{N}, 020^{\circ} 13^{\prime} 16.15^{\prime \prime} \mathrm{E}, 71 \mathrm{~m}$ a.s.1.), col. J. Litavský, 30 August 2015 - 3 October 2015 (UNIBASRB-846, 847, 848, 3 ? juveniles).

Description and comments on morphology. The average body length of the 2 species is: $O$. saxatilis $\widehat{\partial} 3.1-5.2$ $\mathrm{mm}$, of 5.8-6.0 mm, O. parietinus ô $4.0-6.5 \mathrm{~mm}$, of 6.3-7.8 mm (Šilhavý 1956). Apparently, there is a considerable amount of variation in size in the both species, but especially in $O$. saxatilis. In the latter species, the legs appear shorter in proportion to the body size, giving the species a stouter appearance.

The general color of the dorsal surface of the abdomen and cephalothorax is rather lighter in O. saxatilis. Opilio saxatilis has a median whitish line or row of light-colored spots, which is very characteristic. Opilio parietinus may have a narrow lightish band, but this is never so pronounced. The general light brown and cream banding on the legs and the speckled undersurface of the body are similar in both species.

Opilio saxatilis has 2 rows of 3 blunt spines on the ocularium, occasionally there may be a fourth or fifth spine in a row (Fig. 4). Such variation is not uncommon in Opiliones. In O. parietinus there are 5 or 6 , or rarely 7 , spines in each row (Sankey 1949b).

\section{Discussion}

Opilio saxatilis was unknown from the Serbia until now (Karaman 1995, Čurčić et al. 1999). Finding of this species in Serbia has expanded the current list of harvestman species in the country to 60 . In addition to $O$. saxatilis, the occurrence of other 3 species of Opilio was confirmed in Serbia: Opilio putnik, Opilio ruzickai, and Opilio transversalis (Muráyi 2013).

Opilio saxatilis is xerotolerant and a synanthropic species. This harvestman is not as closely associated with urban areas as $O$. parietinus. The species prefers open habitats, for example arable lands, meadows, etc. Opilio saxatilis occurs also in open shrubbery, border forests, and forest steppes, and rarely in open forests, but it avoids forests with dense herb layer. Opilio saxatilis lives in the top soil layers, below the surface of the soil, and on decomposed wood pieces and stones; it occasionally climbs walls in urban area (Stašiov 2004).

The occurrence of $O$. saxatilis in Serbia is unsurprising because it was recorded in the most neighboring countries. Records from Albania and Bulgaria (Mitov 2000, Mitov and Stoyanov 2004) show that the southern edge of this species' distribution lies south-east of Serbia. However, the precise south-eastern limits of its distribution remains uncertain.

Besides $O$. saxatilis, several other species that occur in neighboring countries was not recorded in Serbia. For example, Opilio parietinus was found in all countries bordering Serbia except for Montenegro (Hadži 1973, Martens 1978, Mitov 2000, Novak 2004, 2005). This also applies for several other species (e.g. Astrobunus laevipes (Canestrini, 1872), Egaenus convexus (C. L. Koch, 1835), Gyas titanus Simon, 1879, Lacinius dentiger (C. L. Koch, 1848), Lacinius ephippiatus (C. L. Koch, 1835), Lacinius horridus (Panzer, 1794), Lophopilio palpinalis (Herbst, 1799), Mitopus morio (Fabricius, 1799), Phalangium opilio Linnaeus, 1758, Platybunus bucephalus (C. L. Koch, 1835), Rilaena triangularis (Herbst, 1799), Zachaeus crista (Brullé, 1832), and Trogulus tricarinatus (Linnaeus, 1767)). Apparently, the current Serbian checklist of harvestman is far from complete and the local opiliofauna clearly deserves further attention.

\section{Acknowledgements}

The study was funded by research grant no. 2/0052/15 of the Slovak Grant Agency for Science (VEGA). 


\section{Authors' Contributions}

$\mathrm{JL}$ and OM collected the data; JL and SS determined the material; JL photographed the specimens; MS processed the figures and prepared the map; SS and MS wrote the text.

\section{References}

Becker L (1879) Catalogue des Arachnides ae Belgique. Annales de la Société entomologique de Belgique 12: 1-105.

Becker L (1896) Les arachnides de Belgique. Annales du Musée royal d'histoire naturelle de Belgique 12: 339-369.

Canestrini G (1872) Gli opilionidi italiani. Annali del Museo Civico di Storia Naturale 2: 5-48.

Čurčić BPM, Karaman IM, Tomić VT (1999) On some new and little known epigean harvestman (Opiliones, Arachnida) from West Serbia, Yugoslavia. Archives of Biological Sciences 51 (4): 61-62.

Falconer W (1910) Keys to the families and genera of British spiders, and to the families, genera and species of the British harvestmen and pseudoscorpions. Naturalist 35: 438-447.

Hadži J (1973) Opilionidea. Catalogus faunae Jugoslaviae. Academia Scientiarum et Artium Slovenica 3 (4): 1-24.

Hull JE (1930) A note on north country harvestmen. The Vasculum 12: 124-133.

Karaman IM (1995) Diverziteit faune kosaca (Opiliones, Arachnida) Jugoslavije sa pregledom vrsta od meĐunarodnog značaja.In: Stevanović V, Vasić V (Eds) Biodiverziteit Jugoslavije sa pregledom vrsta od meĐunarodnog značaja. Bioloski fakultet i Ecolibri, Belgrade, 329-335.

Kästner A (1928) Opiliones (Weberknechte, Kanker). Die Tierwelt Deutschlands 8: 1-51.

Koch CL (1839) Übersicht des Arachnidensystems. Zweites Heft. C. H. Zeh'schen, Nürnberg. 38 pp.

Lessert R (1917) Catalogue des invertébrés de la Suisse. Opilions. Fascicule 9. Muséum d'histoire naturelle de Genève, Genève, 79 pp.

Martens J (1978) Weberknechte, Opiliones. Die Tierwelt Deutschlands: 64. Veb Gustav Fischer Verlag, Jena, 464 pp.

Milanovic MM (1990) A survey of the fauna of harvestmen Opiliones, Arachnida of the National Park Durmitor Montenegro, Yugoslavia Bulletin de la Société européenne d〉Arachnologie (Hors Serie) 1: 261-265.

Mitov PG (2000) Contribution to the knowledge of the harvestmen
(Arachnida: Opiliones) of Albania.In: Gajdoš P, Pekar S. (Eds) Proceedings of the 18th European Colloquium of Arachnology. Vol. 19, Supplement 3. Ekológia, Bratislava, 159-169.

Mitov PG, Stoyanov IL (2004) The harvestmen fauna (Opiliones, Arachnida) of the city of Sofia (Bulgaria) and its adjacent regions. In: Penev L, Niemelä J, Kotze DJ, Chipev N (Eds) Ecology of the City of Sofia. Species and Communities in an Urban Environment. PENSOFT Publishers, Sofia and Moscow, 319-354

Muráyi D (2013) Poorly-known phalangiid harvestmen (Opiliones: Phalangioidea) from the Balkans. Opuscula Zoologica 44 (1): $139-156$.

Novak T (2004) An over view of harvestmen (Arachnida: Opiliones) in Croatia. Natura Croatica 13 (3): 231-296.

Novak T (2005). An overview of harvestmen (Arachnida: Opiliones) in Bosnia and Herzegovina. Natura Croatica 14 (4): 301-350.

Pickard-Cambridge O (1890) On the British species of Phalangidea. Proceedings of the Dorset Natural History and Antiquarian Field Club 2: 1-193.

Roewer CF (1912) Revision der Opiliones Palpatores (=Opiliones Plagiostethi). Teil 2.: Familie der Phalangiidae (Subfamilien, Sclerosomini Oligolophinae, Phalangini). Abhandlungen aus dem Gebiete der Naturwissenschaften Verein in Hamburg 20 (1): 1-295.

Sankey JHP (1949a) British harvest-spiders. Essex Naturalist 28 (4): 181-191.

Sankey JHP (1949b) On the Harvestman, Opilio saxatilis (C. L. Koch) Proceedings of the Zoological Society of London 109: 297-300. https://doi.org/10.1111/j.1096-3642.1949.tb00880.x

Savory TH (1945) The Spiders and Allied Orders of the British Isles. F. Warne \& Co., London and New York, 223 pp.

Šilhavý V (1956) Sekáči-Opilionidea. Fauna ČSR 7. Nakladatelství ČSAV, Praha, 274 pp.

Šilhavý V (1938) Význam tvaru kopulačních orgánů v soustavě sekáčů a revise některých evropskych druhů rodu Opilio Herbst. Sborník př́rodovědného klubu 3: 7-20.

Simon E (1879) Les arachnides de France. Contenant les ordres des chernetes, scorpiones et opiliones, 7 Librarie Encyclopediquede Roter, Paris, 379 pp

Staręga W (1966) Kosarze (Opiliones) Bieszczad. Fragmenta Faunistica $13: 145-157$.

Stašiov S (2004) Kosce (Opiliones) Slovenska. Technical University in Zvolen, Zvolen, $119 \mathrm{pp}$

Todd V (1948) Key to the determination of the British harvestmen (Arachnida, Opiliones). The Entomologist's Monthly Magazine 84: 109-113. 